\title{
Acute Kidney Injury sebagai Prediktor Kematian pada Pasien Sindrom Syok Dengue di RSUP Dr. Sardjito
}

Budyarini Prima Sari, Eggi Arguni, Cahya Dewi Satria

Bagian Ilmu Kesehatan Anak Fakultas Kedokteran Universitas Gadjah Mada / RSUP dr. Sardjito, Yogyakarta

Latar belakang. Sindrom syok dengue (SSD) merupakan salah satu dari spektrum kompleks dan berat infeksi dengue. Tatalaksana SSD masih merupakan tantangan besar, khususnya pada kondisi yang terjadi komplikasi multiorgan. Acute kidney injury (AKI) sebagai salah satu penyakit ginjal terkait infeksi dengue perlu diperhitungkan dampaknya pada SSD.

Tujuan. Untuk menentukan frekuensi, keparahan, dan prediktor mortalitas pada pasien SSD berdasarkan kondisi AKI.

Metode. Dilakukan penelitian kohort retrospektif pada anak usia 1 bulan sampai 18 tahun yang dirawat di RSUP Dr. Sardjito dengan diagnosis SSD sejak Januari 2010 sampai Desember 2015. Data produksi urin dan rumus formula Pottel digunakan untuk menghitung laju filtrasi glomerulus. Uji chi square digunakan untuk menganalisis hubungan antara data klinis dan luaran pasien sindrom syok dengue

Hasil. Dari 151 anak yang memenuhi kriteria, kondisi gangguan ginjal akut terjadi pada 65 pasien (43\%). Berdasarkan kriteria pRIFLE, 42 (62\%) pasien termasuk ke derajat risk, 23 (35\%) pasien derajat injury. Angka kematian pasien SSD di RSUP 21,2\% dan secara signifikan paling tinggi terdapat pada kelompok AKI $(\mathrm{p}=0,000)$ terutama pada kelompok derajat injury $(\mathrm{p}=0,001)$ dengan RR 2,656 (IK95\%:1,494-4,721). Di kelompok AKI, hanya koagulasi intravaskular disseminata (KID) yang berhubungan dengan meningkatnya risiko kematian ( $\mathrm{P}=0,003)$ dengan $\mathrm{RR} 2,483$ (IK95\%:1,318-4,677).

Kesimpulan. Insiden AKI pada SSD lebih tinggi dari yang diperkirakan dan berhubungan dengan kematian pasien SSD. Sari Pediatri 2018;19(5):252-9

Kata kunci: acute kidney injury, sindrom syok dengue, kematian

\section{Acute Kidney Injury as A Predictor of Mortality in Dengue Shock Syndrome Patients at Dr. Sardjito General Hospital}

Budyarini Prima Sari,Eggi Arguni, Cahya Dewi Satria

Background. Dengue shock syndrome (DSS) is one of the severe and complex spectrum of dengue infection. DSS is still a big challenge in management especially for those who have its complications in multy organs. Acute kidney injury (AKI) as one of the acute kidney disease associated dengue infection is needed to be quantify for its impact in DSS.

Objective. To determine the frequency, severity and predictor of mortality in DSS patients based on AKI condition.

Methods. We retrospectively reviewed medical records of children aged 1 month to 17 years old hospitalized with diagnosis of dengue shock syndrome in Sardjito hospital from January 2010 to December 2015. We recorded urine output data and Pottel formula to calculate estimated-glomerular filtration rate. Chi-square test was performed to analyze the assocation between clinical data and outcome of DSS patients.

Results. Of 151 children enrolled, AKI occured in 65 patients (43\%). Using the pRIFLE criteria, 42 (62\%) patients were in the risk stage, $23(35 \%)$ patients in the injury stage. The mortality rate of DSS patients in Sardjito Hospital was $21.2 \%$ and it's significantly higher in the patients with AKI group $(\mathrm{P}=0,000)$ especially in AKI injury stage $(\mathrm{P}=0,001)$ with RRs of 2.656 (95\% CI 1.494 to 4.721). In the AKI group, only disseminated intravascular coagulation (DIC) was associated with increase risk of mortality $(\mathrm{P}=0.003)$ with RRs of 2.483 (95\% CI 1.318 to 4.677 ).

Conclusion. The incidence of AKI is much higher than previously thought and it's associated with the mortality in DSS patients. Sari Pediatri 2018;19(5):252-9

Keywords: acute kidney injury, dengue shock syndrome, mortality

Alamat korespondensi: Budyarini Prima Sari. Bagian Ilmu Kesehatan Anak, Fakultas Kedokteran Universitas Gadjah Mada /RSUP Dr. Sardjito, Jl. Kesehatan No.1 Sekip Yogyakarta 55284. E-mail: budyarini.prima.s@mail.ugm.ac.id 
I nfeksi dengue merupakan penyakit virus yang ditularkan oleh nyamuk Aedes aegypti yang perkembangannya paling cepat di dunia. Pada tahun 2013, WHO (World Health Organization) melaporkan insiden infeksi dengue meningkat tajam dalam 50 tahun terakhir. Ditemukan sekitar 50 juta kasus dengue di dunia setiap tahunnya, 500 ribu di antaranya merupakan kasus berat, yaitu demam berdarah dengue (DBD) dan sindrom syok dengue (SSD) yang memerlukan perawatan intensif. ${ }^{1}$ Proporsi terbesar adalah pasien anak berusia kurang dari 5 tahun (90\%) dan 2,5\% di antaranya meninggal. ${ }^{2}$ Spektrum klinis infeksi dengue yang menyebabkan kematian terbanyak pada anak adalah SSD. Kondisi SSD ini ditandai dengan adanya kebocoran plasma hebat yang berakibat hipovolemia.

Indonesia merupakan daerah endemis infeksi dengue dengan sebaran di seluruh wilayah tanah air. Karyanti $\mathrm{dkk}^{3}$ melaporkan bahwa insiden DBD meningkat dalam kurun waktu 45 tahun terakhir, epidemi tertinggi di tahun 2010. Jumlah kasus DBD dilaporkan 156.086 kasus dengan angka kematian 1358 (CFR=0,87\%). Pada tahun 2013, jumlah kasus DBD yang dilaporkan 112.511 kasus dengan jumlah kematian 871 orang/angka kesakitan, incidence rate (IR) $=45,85$ per 100.000 penduduk dan $\mathrm{CFR}=0,77 \%$. Pada tahun 2013, di Daerah Istimewa Yogyakarta,terdapat 96 kasus per 100.000 penduduk dengan $\mathrm{CFR}=0,48 \%$ Pada tahun 2014 terdapat 99.499 kasus DBD dengan angka kematian 905 (CFR=0,91\%) Jumlah tersebut menurun dibandingkan tahun 2013. ${ }^{4}$ Berdasarkan data rekam medik di RSUP Sardjito didapatkan 197 kasus pasien dengan SSD dalam kurun waktu Januari 2010-Desember 2015. Jumlah kasus terbanyak pada tahun 2013 dan 2015 dengan persentase 28\%. Angka kematian pasien SSD dalam 5 tahun terakhir di RSUP Sardjito $17,7 \%$ (35 pasien).

Acute kidney injury (AKI) merupakan salah satu dari komplikasi SSD pada pasien anak. Kondisi AKI sendiri seringkali tidak terdiagnosis sejak awal yang akhirnya dapat mengurangi kewaspadaan terhadap perburukan ginjal pasien SSD. Penelitian retrospektif sebuah serial kasus menunjukkan bahwa AKI berhubungan dengan lama rawat di rumah sakit dan mortalitas yang tinggi. ${ }^{5}$ Beberapa mekanisme yang diperkirakan menjadi patogenesis AKI karena infeksi dengue, antara lain, aktivitas langsung virus di glomerulus ginjal, hipoperfusi ginjal akibat syok berkepanjangan, intabilitas hemodinamik, rabdomiolisis, dan injuri glomerular akut. ${ }^{5}$
Penelitian ini bertujuan untuk mengetahui frekuensi, derajat keparahan AKI serta untuk mengetahui validitas AKI sebagai prediktor kematian pada pasien SSD.

\section{Metode}

Penelitian kohort retrospektif pada anak usia 1 bulan - 18 tahun yang dirawat di RSUP Dr. Sardjito dengan SSD dalam kurun waktu Januari 2010 - Desember 2015. Kriteria inklusi adalah pasien dengan diagnosis SSD usia 0-18 tahun yang memenuhi kriteria WHO. Pasien akan dieksklusi bila data rekam medis tidak lengkap, tidak adanya data blood urea nitrogen (BUN) dan kreatinin pada pemeriksaan kimia darah serta adanya penyakit ginjal kronis. Data dikumpulkan dari rekam medis pasien menggunakan isian, meliputi data demografi (usia, jenis kelamin, tanggal masuk), diagnosis penyerta, profil hematologi saat datang (leukosit, hemoglobin, hematokrit, dan trombosit), serologi anti dengue, kimia darah penanda fungsi ginjal (BUN, kreatinin), volume urin per kilogram berat badan pada 6 jam pertama pasien datang sertaluaran SSD (hidup atau meninggal). Penentuan derajat AKI menggunakan kriteria RIFLE anak atau pediatric RIFLE (pRIFLE) yaitu menggunakan nilai laju filtrasi glomerulus (LFG) atau volume urin per kilogram berat badan per jam.

Penghitungan LFG atau glomerular filtration rate (GFR) menggunakan formula Pottel karena beberapa pasien tidak memiliki data tinggi badan seperti yang dibutuhkan pada formula Schwartz untuk menghitung LFG (Gambar 1).

$\operatorname{LFG}\left(\mathrm{mL} / \mathrm{min} / 1,73 \mathrm{~m}^{2}\right)=107,3:\left\{\frac{\begin{array}{c}\text { kreatinin } \\ \text { serum }\end{array}}{\mathrm{Q}}\right\}$

Gambar 1. Rumus formula Pottel ${ }^{6}$

Pada formula Pottel ini digunakan median kreatinin serum $(\mathrm{Q})$ untuk masing-masing kelompok usia.

Sampel penelitian adalah seluruh pasien SSD yang dirawat di RSUP dr. Sardjito sejak Januari 2010 - Desember 2015. Sebanyak 151 sampel memenuhi kriteria penelitian ini. Uji chi-quare digunakan untuk menganalisis hubungan antara 
AKI dengan luaran kematian pasien SSD. Beberapa data karakteristik memiliki distribusi tidak normal sehingga ditampilkan dalam bentuk median. Semua nilai $p$ adalah berpasangan dan nilai $p<0,005$ dianggap signifikan. Perhitungan statistik dikerjakan dengan menggunakan piranti lunak SPSS version 17.0 for windows tahun 2007, SPSS inc, Chicago-Illinois, USA.

Penelitian ini telah mendapatkan persetujuan dari Komisi Etik Fakultas Kedokteran Universitas Gadjah Mada.

\section{Hasil}

Sebanyak 197 anak usia 1 bulan - 18 tahun dengan sindrom syok dengue dirawat di RSUP Dr. Sardjito selama periode yang ditetapkan untuk penelitian. Dua puluh rekam medik tidak bisa dikeluarkan terkait proses retensi. Tujuhbelas anak dieksklusi karena data yang tidak lengkap dan 9 anak dieksklusi karena tidak memiliki data BUN dan kreatinin. Dari 151 anak yang memenuhi kriteria, $32(21,2 \%)$ meninggal dunia. Sebagian besar anak $(64,9 \%)$ berusia $\geq 5$ tahun dengan proporsi laki-laki : perempuan adalah $0,8: 1$. Kami mengidentifikasi pasien dengan kondisi AKI 65 (43\%) dan tidak AKI 86 (56,9\%). Tidak didapatkan perbedaan bermakna profil hematologi saat masuk di kelompok AKI dan tidak AKI dengan median nilai hematokrit di kedua kelompok adalah 40,1\% dan $40,7 \%$. Terdapat perbedaan yang bermakna pada nilai median LFG di kedua kelompok. Karakteristik subyek penelitian tertera pada Tabel 1 .

Berdasarkan kriteria pRIFLE, derajat AKI yang ditemukan meliputi fase risk dan injury. Pasien dengan AKI fase risk 64,6\% (42 pasien) dan pasien dengan AKI fase injury 35,3\% (23 pasien).

Pasien SSD yang dirawat di RSUP Sardjito memiliki beberapa macam komplikasi dan penyulit selama perawatan. Disseminated intravascular coagulation (DIC) merupakan kondisi terbanyak pada kelompok AKI, sedangkan sepsis ditemukan terbanyak pada kelompok tidak AKI, diikuti dengan DIC. Beberapa komplikasi atau penyulit lain pada pasien SSD tertera pada Tabel 2.

Tigapuluh dua pasien SSD meninggal dan 27 di antaranya merupakan kelompok pasien dengan AKI.

Tabel1.Karakteristik subyek penelitian

\begin{tabular}{|c|c|c|}
\hline Karakteristik & AKI $(n=65)$ & Tidak AKI $(\mathrm{n}=86)$ \\
\hline \multicolumn{3}{|l|}{ Usia, tahunn (\%) } \\
\hline$<1$ & $6(9,2)$ & $9(10,4)$ \\
\hline$>5$ & $37(56,9)$ & $61(70,9)$ \\
\hline \multicolumn{3}{|l|}{ Jenis kelamin, $\mathrm{n}(\%)$} \\
\hline Laki - laki & $32(49,2)$ & $39(45,3)$ \\
\hline Perempuan & $33(50,7)$ & $47(54,6)$ \\
\hline Hari demam, hari (median) & $5(3-6)$ & $5(4-8)$ \\
\hline \multicolumn{3}{|c|}{ Profil hematologi saat masuk (median) } \\
\hline Trombosit $\left(10^{6} / \mu \mathrm{L}\right)$ & $19,0(0-120)$ & $26(5-184)$ \\
\hline Hematokrit (\%) & $40,1(23,1-56,9)$ & $40,7(12,1-59,3)$ \\
\hline Leukosit $\left(10^{6} / \mu \mathrm{L}\right)$ & $5,49(1,1-23,5)$ & $5,4(1,8-23)$ \\
\hline \multicolumn{3}{|l|}{ Fungsi ginjal (median) } \\
\hline BUN (mg/dL) & $16(5,9-39)$ & $10,3(3,6-25,5)$ \\
\hline Kreatinin $(\mathrm{mg} / \mathrm{dL})$ & $0,7(0,24-6,8)$ & $0,5(0,2-1,1)$ \\
\hline Diuresis (ml/kgBB/jam) & $1,0(0-8,3)$ & $1,5(0,5-5,8)$ \\
\hline eGFR (ml/menit/1,75 m²) & $55,8(25,5-121,9)$ & $87,6(63,1-188,2)$ \\
\hline \multicolumn{3}{|l|}{ Serologi anti dengue, $n(\%)$} \\
\hline Infeksi primer & $11(16,9)$ & $12(13,9)$ \\
\hline Infeksi sekunder & $41(63,1)$ & $62(72,1)$ \\
\hline \multicolumn{3}{|l|}{ Luaran, n (\%) } \\
\hline Meninggal & $27(41,5)$ & $5(5,8)$ \\
\hline Hidup & $38(58,4)$ & $81(94,1)$ \\
\hline Lama perawatan, hari (median) & $5(0-22)$ & $5(1-56)$ \\
\hline
\end{tabular}


Secara signifikan mortalitas pada kelompok AKI 41,5\% bila dibandingkan dengan kelompok tidak AKI 5,8\% $(\mathrm{p}=0,000)$. Didapatkan risiko relatif 7,145 (IK95\%: 2,910-17,542) untuk mortalitas pasien dengan AKI.
Pada kelompok AKI angka kematian meningkat pada AKI fase injury $(69,6 \%)$ bila dibandingkan dengan fase risk 26,2\% ( $\mathrm{p}=0,001$; Tabel 3). Risiko untuk terjadinya kematian pada AKI fase injury

Tabel 2. Komplikasi dan penyulit pada pasien SSD

\begin{tabular}{lcc}
\hline Gejala klinis & AKI $(\mathrm{n}=65)$ & Tidak AKI $(\mathrm{n}=86)$ \\
\hline Sepsis, $\mathrm{n}(\%)$ & $25(38,4)$ & $20(23,2)$ \\
DIC, $\mathrm{n}(\%)$ & $29(44,6)$ & $15(17,4)$ \\
Edem paru, n (\%) & $15(23,1)$ & $16(18,6)$ \\
Ensefalopati, n (\%) & $16(24,6)$ & $8(9,3)$ \\
Obesitas dan overweight, n (\%) & $8(12,3)$ & $11(12,7)$ \\
AKI, n (\%) & & \\
Risk & $42(64,6)$ & \\
Injury & $23(35,3)$ & $86(100)$ \\
Normal & & \\
\hline
\end{tabular}

Tabel 3. Hubungan AKI dengan luaran kematian dan luaran kematian

\begin{tabular}{|c|c|c|c|c|c|c|}
\hline & \multicolumn{5}{|c|}{ Luaran } & \multirow{3}{*}{$\mathrm{p}$} \\
\hline & \multicolumn{2}{|c|}{ Meninggal } & \multicolumn{2}{|c|}{ Hidup } & & \\
\hline & $\mathrm{n}$ & $\%$ & $\mathrm{n}$ & $\%$ & & \\
\hline \multirow[t]{3}{*}{ Klinis } & AKI & 27 & 41,5 & 38 & 58,5 & 0,000 \\
\hline & Tidak AKI & 5 & 5,8 & 81 & 94,2 & \\
\hline & Total & 32 & 21,2 & 119 & 78,8 & \\
\hline \multirow[t]{3}{*}{ AKI } & Injury & 18 & 69,6 & 7 & 30,4 & 0,001 \\
\hline & Risk & 11 & 26,2 & 31 & 73,8 & \\
\hline & Total & 27 & 41,5 & 38 & 58,5 & \\
\hline
\end{tabular}

Tabel 4. AKI dan berbagai faktor risiko

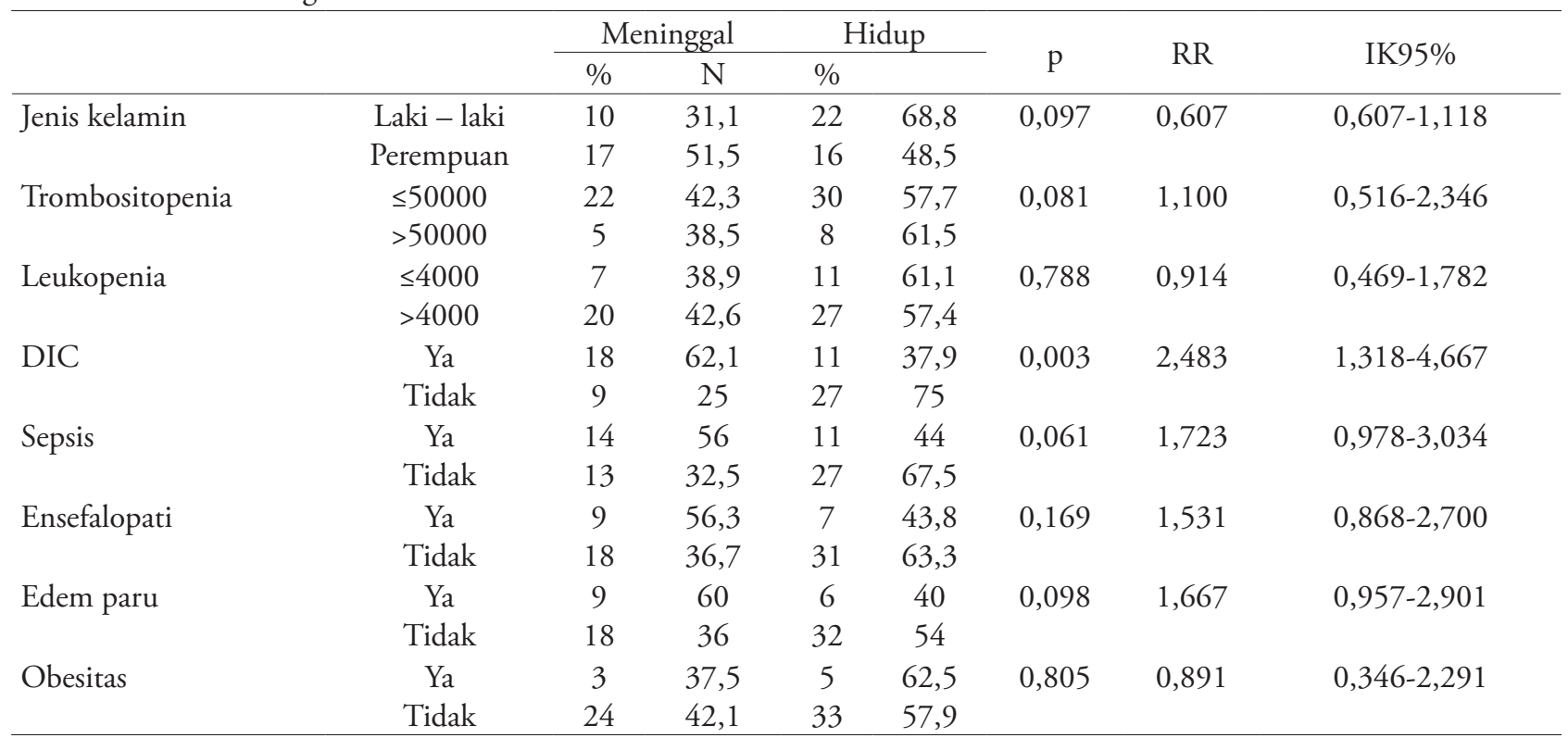


2,656 kali (IK95\%:1,494-4,721). Berdasarkan analisis bivariat seperti yang tertera pada Tabel 4 , variabel yang berpengaruh terhadap kematian pada kelompok AKI hanya kondisi DIC $(\mathrm{p}=0,003)$ dengan risiko relatif 2,483 (IK95\%:1,318-4,677).

\section{Pembahasan}

Demam berdarah dengue dengan syok merupakan kegawatan dan sering menyebabkan kematian. Dari 151 anak usia 1 bulan-18 tahun dengan SSD di RSUP dr. Sardjito tahun 2010-2015, 32 (21\%) pasien meninggal. Pada penelitian kami, frekuensi jenis kelamin laki-laki dan perempuan hampir sama, 47\% dan 52\%. Penelitian SSD di Jakarta dan Vietnam juga mendapatkan frekuensi yang hampir sama antara laki-laki dan perempuan. ${ }^{78}$ Perempuan lebih banyak meninggal (65\%, 21 pasien). Hal tersebut mungkin disebabkan perbedaan respon imun antara laki-laki dan perempuan, respon imun dan kerentanan perempuan untuk terjadinya peningkatan permeabilitias kapiler lebih tinggi sehingga dapat lebih cepat mengalami syok. ${ }^{9,10}$ Hasil penelitian kami menunjukkan jumlah terbanyak pasien SSD ada pada kelompok usia lebih dari 5 tahun. Sebagian besar pasien datang dengan demam hari ke-5, sedangkan penelitian oleh Wills $\mathrm{dkk}^{8}$ melaporkan rata-rata subyek penelitian dirawat di hari demam ke-5 sampai dengan 7.

Infeksi sekunder merupakan jenis infeksi dengue paling banyak (81\%). Hal ini sesuai dengan teori bahwa infeksi dengue berat akan terjadi pada secondary heterolog infection. Antibodi residu dari infeksi pertama akan membentuk kompleks dengan virus infeksi sekunder yang dapat mengaktivasi sistem imun dan sitokin tertentu. Pada pasien dengan kondisi gagal ginjal, TNF dan IL6 dilaporkan lebih banyak ditemukan. ${ }^{11}$

Hasil penelitian kami memperlihatkan bahwa kondisi AKI terjadi pada 65 (43\%) pasien. Jumlah ini lebih tinggi bila dibandingkan dengan beberapa penelitian sebelumnya di Thailand $(0,9 \%)$, Brazil (4\%), dan Pakistan (13,3\%). ${ }^{5}$ Sebagian besar subyek penelitian mengalami AKI fase risk (64,6\%), sisanya failure $(35,3 \%)$. Jumlah ini lebih banyak dibanding yang diperkirakan dan tidak terdiagnosis di awal karena pasien masih memiliki produksi urin yang baik dalam 6 jam pertama, tetapi sudah didapatkan peningkatan kreatinin serum. Kuo dkk ${ }^{12}$ melaporkan bahwa insiden AKI fase risk lebih banyak daripada injury (26\% dari 273 pasien dengan AKI pada infeksi dengue). Penelitian dengan hasil yang sama oleh Khalil $\mathrm{dkk}^{13}$ juga melaporkan $64 \%$ pasien dengan AKI derajat ringan.

Acute kidney injury merupakan penurunan fungsi ginjal mendadak yang ditandai oleh peningkatan reversibel kreatinin serum dan produk limbah nitrogen serta ketidakmampuan ginjal mengendalikan gangguan keseimbangan cairan, elektrolit, dan asam basa. ${ }^{14}$ Diagnosis AKI ditegakkan dengan memperhitungkan LFG atau peningkatan kreatinin serum serta produksi urin. Pada penelitian ini, kami menggunakan formula Pottel untuk menghitung LFG karena beberapa pasien tidak memiliki data tinggi badan yang dibutuhkan formula Schwartz untuk menghitung LFG pada anak. Kondisi gawat darurat pasien SSD juga tidak memungkinkan melakukan pengukuran tinggi badan secara standar baik ketika pasien masih di IGD maupun ketika pasien sudah di ruang rawat intensif. Formula Pottel menggunakan median dari nilai kreatinin serum sesuai usia dan jenis kelamin. ${ }^{6}$

Acute kidney injury yang terjadi pada kasus SSD adalah tipe pre renal dan AKI fase risk sendiri mempunyai prognosis yang lebih baik karena kelainan fungsi ginjal bersifat reversibel, yang dapat membaik dengan manajemen syok yang adekuat dan pemberian terapi cairan yang optimal. Mekanisme dan patogenesis AKI pada SSD saat ini tidak hanya berpusat pada teori hipoperfusi saja. Mekanisme imunologi karena invasi langsung virus dengue pada ginjal dapat menyebabkan kerusakan glomerulus dan tubulus ginjal. Jessie $\mathrm{dkk}^{15}$ melaporkan ditemukannya antigen virus dengue pada tubulus ginjal pasien DBD dan SSD melalui pemeriksaan imunohistokimia.

Penelitian kami mengidentifikasi bahwa secara statistik terdapat hubungan antara AKI dan kematian. Pasien dengan AKI mempunyai kemungkinan 7,1 kali untuk meninggal bila dibandingkan dengan pasien yang tidak AKI. Hal ini berhubungan dengan fungsi ginjal itu sendiri sebagai organ suportif pengatur keseimbangan cairan pada kondisi syok pasien dengue. Hipovolemia prerenal pada kondisi SSD dapat memperberat fungsi ginjal karena adanya hipoperfusi sehingga kadar kreatinin serum meningkat dan berakibat ginjal tidak berfungsi dalam mempertahankan keseimbangan cairan tubuh.

Fase injury memiliki hubungan dengan kematian bila dibandingkan dengan fase risk dan memiliki 
kemungkinan 2,656 kali untuk peningkatan mortalitas pasien. Kami juga menganalisis beberapa faktor risiko pada SSD. Dari analisis statistik didapatkan, pada setting penelitian kami hanya DIC yang memiliki hubungan bermakna dengan kematian dalam kelompok AKI, dan ini berarti bahwa pasien AKI yang mengalami DIC memiliki risiko 2,483 kali untuk meninggal. Kriteria RIFLE tidak dapat membedakan dimana letak lesi kerusakan ginjal. Kerusakan fungsi ginjal digambarkan melalui penurunan LFG pada masing-masing fase. Pada AKI fase injury, terjadi penurunan LFG 50\%, ditambah dengan kondisi lain, seperti sepsis atau DIC maka akan memperparah kondisi iskemia pada sel ginjal sehingga kematian terjadi karena fungsi pengaturan cairan serta asam basa terganggu. Dalam penelitian ini, data kreatinin serum hanya diambil di awal perawatan dan tidak semua pasien dilakukan pemeriksaan evaluasi kreatinin. Namun, pada beberapa pasien kami dapatkan kadar kreatinin meningkat dari nilai sebelumnya pada pemeriksaan evaluasi. Idealnya, dilakukan penilaian ulang kadar kreatinin serum setelah kondisi SSD teratasi untuk melihat kecenderungan perbaikan kadar kreatinin serum tersebut.

Monitor ketat tanda bahaya infeksi dengue berat dan volume cairan tubuh merupakan hal penting untuk mencegah AKI. Pada penelitian kami, kondisi AKI dapat membaik hanya dengan terapi cairan dan manajemen syok yang adekuat tanpa dilakukan hemodialisis. Analisis faktor prediktor terhadap kematian pasien SSD yang menjadi sampel penelitian kami bisa disebabkan karena terapi cairan inisial tidak adekuat. Sebagian besar pasien merupakan pasien rujukan dengan dokumentasi terapi cairan tidak optimal dan beberapa pasien datang sudah dengan kondisi oliguria hingga anuria serta syok berkepanjangan. Kematian pada syok dengan terapi cairan yang baik dapat diturunkan hingga $0,2 \%$, tetapi jika manajemen cairan tidak adekuat hingga terjadi syok berkepanjangan maka angka kematian dapat meningkat $12 \%-44 \%$ karena komplikasi multi organ termasuk ginjal. ${ }^{16}$

\section{Kesimpulan}

Acute kidney injury sebagai suatu komplikasi yang sering dari infeksi dengue berat dapat meningkatkan morbiditas dan mortalitas pasien. Kondisi AKI terutama derajat injury dapat digunakan sebagai prediktor kematian penderita SSD.

\section{Daftar pustaka}

1. Bhat R, Varma C, Bhatt S. Dengue fever with co-infection : A case series in children. JMID 2014;1:S62-S64.

2. World Health Organization. Comprehensive guidelines for prevention and control of dengue and dengue haemorrhagic fever, revised and expanded edition. Geneva: WHO;2011.

3. Karyanti MR, Uiterwaal CSPM, Kusriastuti R, Hadinegoro SR, Rovers MM, Heesterbeek H dkk. The changing incidence of dengue hemorrhagic fever in Indonesia : a 45-year registrybased analysis. BMC Infect Dis 2014;14:412.

4. Ditjen PP\&PL, Kementerian Kesehatan Republik Indonesia. Profil kesehatan Indonesia tahun 2013. Jakarta: Kementerian Kesehatan Republik Indonesia; 2013

5. Oliveira JFP, Burdmann EA. Dengue-associated acute kidney injury. Clin Kidney J 2015;8:681-5.

6. Blufpand HN, Westland R, Wijk JAE, Roelandse EA, Kaspers GJL, Bokenkamp A. Height-independent estimation of glomerular filtration rate in children: an alternative to the Schwartz equation. J Pediatr 2013;163:1722-7.

7. Dewi LP, Nurfitri E. Pediatric logistic organ dysfunction score as a predictive tool of dengue shock syndrome outcome. Paediatr Indones 2012;52:72-7.

8. Wills BA, Oragui EE, Stephens AC. Coagulation abnormalities in dengue hemorrhagic fever : serial investigation in 167 Vietnamese children with dengue shock syndrome. Clin Infect Dis 2002;35:277-85.

9. Whitehorn J, Simmons CP. The pathogenesis of dengue. Vaccine 2011;29:7221-8.

10. Anders LL, Nguyer NM, Chau NVV, Hung NY, Thuy TT, Lien LB. Epidemiological factors associated with dengue shock syndrome and mortality in hospitalized dengue patients in Ho Chi Minh City, Vietnam. Am J Trop Med Hyg 2011;84:127-34.

11. Pecoits-Filho R, Heimburger O, Barany P, Suliman M, Fehrman-Ekholm I, Lindholm B, Stenvinkel P: Associations between circulating inflammatory markers and residual renal function in CRF patients. Am J Kidney Dis 2003;41:1212 -18 .

12. Kuo MC, Lu PL, Hwang SJ. Impact of renal failure on the outcomeof dengue viral infection. Clin J Am Soc Nephrol 2008;3:1350-6.

13. Khalil MAM, Sarwar S, Chaudry MA, Maqbool B, Khalil Z, Tan J dkk. Acute kidney injury in dengue virus infection. Clin Kidney J 2012;5:390-4.

14. Alatas H. Gagal ginjal akut. Dalam : Noer SM, Soemyarso NA, 
penyunting. Jakarta:Kompendium nefrologi anak 2011;3:20714.

15. Jessie K, Fong MY, Devi S, Lam SK, Wong KT. Localization of dengue virus in naturally infected human tissues by immunohistochemistry and in situ hybridization. J Infect Dis
2004;189:1411-8.

16. Nhan NT, Phuong CXT, Kneen R. Acute management of dengue shock syndrome: a randomized double-blind comparison of 4 intravenous fluid regimens in the first hour. Clin Infect Dis2001;32:204-13. 


\section{Lampiran}

Kriteria RIFLE anak $^{14}$

\begin{tabular}{llc}
\hline \multirow{2}{*}{ Kategori } & \multicolumn{2}{c}{ Pediatric modified RIFLE criteria } \\
\cline { 2 - 3 } & LFG & Produksi urin \\
\hline Risk $(R)$ & Peningkatan kreatinin 1,5 kali atau LFG menurun sampai $25 \%$ & $<0,5 / \mathrm{kgBB} /$ jam selama 6 jam \\
Injury $(I)$ & Peningkatan kreatinin 2 kali atau LFG menurun sampai $50 \%$ & $<0,5 / \mathrm{kgBB} /$ jam selama 12 jam \\
Failure $(F)$ & Peningkatan kreatinin $3 \mathrm{kali}$ atau LFG menurun sampai $75 \%$ & $<0,3 / \mathrm{kgBB} / \mathrm{jam}$ selama 24 jam atau anuria \\
& atau LFG $<35 \mathrm{ml} / \mathrm{menit} / 1,75 \mathrm{~m}^{2}$ & selama 12 jam \\
Loss $(L)$ & Gagal ginjal menetap $>4$ minggu & \\
End-stage $(E)$ & Gagal ginjal menetap $>3$ bulan & \\
\hline
\end{tabular}

Median konsentrasi kreatinin serum untuk kelompok umur ${ }^{6}$

\begin{tabular}{|c|c|c|c|}
\hline Usia & Semua pasien & Laki - laki & Perempuan \\
\hline Neonatus & 0,54 & - & - \\
\hline 1 bulan $-<1$ tahun & 0,25 & - & - \\
\hline $1-<2$ tahun & 0,27 & - & - \\
\hline $2-<3$ tahun & 0,30 & - & - \\
\hline $3-<4$ tahun & 0,33 & - & - \\
\hline $4-<5$ tahun & 0,36 & - & - \\
\hline $5-<6$ tahun & 0,38 & - & - \\
\hline $6-<7$ tahun & 0,43 & - & - \\
\hline $7-<8$ tahun & 0,45 & - & - \\
\hline $8-<9$ tahun & 0,47 & - & - \\
\hline $9-<10$ tahun & 0,50 & - & - \\
\hline $10-<11$ tahun & 0,52 & - & - \\
\hline $11-<12$ tahun & 0,54 & - & - \\
\hline $12-<13$ tahun & 0,57 & - & - \\
\hline $13-<14,5$ tahun & 0,61 & - & - \\
\hline $14,5-<15,5$ tahun & - & 0,68 & 0,62 \\
\hline $15,5-<16,5$ tahun & - & 0,78 & 0,68 \\
\hline $16,5-<17,5$ tahun & - & 0,82 & 0,70 \\
\hline $17,5-<18,5$ tahun & - & 0,85 & 0,71 \\
\hline
\end{tabular}

